\title{
The Proportion of Human Immunodeficiency Virus Patients in Circumcised and Uncircumcised Men with Unsafe Sexual Practices in Special Care Center in General Hospital Center Haji Adam Malik Hospital Medan
}

\author{
Juliyanti, Irwan Fahry Rangkuti, Remenda Siregar \\ Department of Dermato-veneorology, Faculty of Medicine, University of North Sumatera \\ General Hospital Center Haji Adam Malik Medan, Indonesia
}

\begin{abstract}
Background: The incidence of HIV was found to be higher in uncircumcised men compared to circumcised men. Circumcision was known to protect and fight against the acquired HIV infection. HIV infection was classified into sexual transmitted infections since it is mostly transmitted sexually (95\%). The risk was higher in unsafe sexual practices, such as having multiple sexual partners and not using protections like condoms.

Subjects and methods: This was a descriptive study with cross-sectional design study. There were 340 patients who came to the special care center in General Hospital Center Haji Adam Malik Hospital and participated in this study. Data such as history taking and clinical examination were then collected.

Result: The proportion of HIV patients with unsafe sexual practices was lower in circumcised men group, which was 141 patients (41.5\%), compared to uncircumcised men group which was 199 patients (58.5\%).

Conclusion: The proportion of HIV infection in uncircumcised men with unsafe sexual practices was higher than in circumcised men.
\end{abstract}

Keywords: HIV, Circumcision, Sexual practice

Korespondensi:

Juliyanti. Department of Dermato-veneorology, Faculty of Medicine, University of North Sumatera, Indonesia. Email: . Mobile: 082174346045.

\section{BACKGROUND}

Human immunodeficiency virus (HIV) infection is one of the infections with progressive development in the world. There were 36.1 million people estimated to be infected by HIV worldwide (Katz and Wright, 2008). World Health Organization (WHO) estimates that in 1999, there will be 340 million new cases of sexual transmitted infections every year (Katz and Wright, 2008; Plank, 2010). HIV is transmitted by several ways, such as horizontally by sexual practice and infected blood or vertically, which is from infected mothers to their babies (Plank, 2010; Roloff et al., 2011).
Based on the data from Health Department of North Sumatra until September 2012, the population of HIV infection in men was 931 people and in women was 444 people. The data indicated that HIV infection incidence was higher in men than women. In the other hand, the cumulative number of HIV infection based on risk factor showed that the highest risk factor was in the heterosexual population which consisted of 764 people (Dinas Kesehatan Provinsi Sumatera Utara, 2012).

The incidence of HIV was found to be higher in uncircumcised men group than in circumcised men group (Kurt et al., 2011). Circumcision was known to protect and 
fight against acquired HIV infection (Simon et al., 2006). There were at least 9 studies conducted in The United States which showed that circumcision played role in lowering the prevalence of HIV infection (Roloff et al., 2011; Simon et al., 2006; Brewer, 2007).

Circumcision is the removal of the preputium that covers the penis (Roloff et al., 2011; Simon et al., 2006; Serwadda et al., 2012). This is a minor surgery which had been done the most worldwide, either by doctors, paramedics, or a circumcision specialist (Roloff et al., 2011; Simon et al., 2006).

The purpose of circumcision in the medical aspect is to maintain the hygiene of penis from smegma and remaining urine, to prevent infection of glans penis or preputium, and to prevent penile cancer (Kurt et al., 2011; Sancez et al., 2011).

Preputiumprotects glans by working actively as a barrier against contamination and maintaining a moist environment around the glans. In addition, it also plays role in sexual pleasure. Preputium cannot be retracted early in life (Kurt et al., 2011; Simon et al., 2006). The development of penis, accumulation of dermis epithelium, and erectile activity since the beginning of third year until fourth year cause the preputiumto be retracted eventually (Sancez et al., 2011).

Unsafe sexual practice is a sexual practice with multiple sexual partners and not using protections. This can increase the incidence of sexual transmitted infections in the community (Plank, 2010; Kurt et al., 2011; Sancez et al., 2011).

HIV infection is classified into sexual transmitted infections because it is transmitted mostly by sexual practice (95\%) (Plank, 2010; Roloff et al., 2011). The risk will be higher in unsafe sexual practices such as having multiple sexual partners and not using protections such as condoms (Roloff et al., 2011; Brewer et al., 2007; Serwadda 2012; Wanner, 2009).

The pathogenesis of the increasing incidence of HIV infection in uncircumcised men was predicted to be caused by the disruption of the protective mechanism of circumcision. The preputium of uncircumcised men contained lot of langerhans cells and less keratinization, which caused viruses to develop easily (Serwadda 2012; Bailey et al., 2007; Siegfried et al., 2009).

Several studies in developing countries showed that there was an increasing incidence of HIV infection in uncircumcised men compared to circumcised men (Kurt et al., 2011; Wanner et al., 2009; Bailey et al., 2011; Siegfried et al., 2009).

A study conducted by America Academy of Pediatric showed that circumcision in men would decrease the risk of sexual transmitted infections. ${ }^{13}$ The result which stated that circumcision could decrease the risk of sexual transmitted infections is still controversial (Lissouba, 2011).

From 2005 to 2007, three randomized controlled trials in Sub-Saharan Africa showed that circumcision in men could protect them from HIV infection when having sex with women (Szabo dan Short, 2000). A study which was conducted in Uganda, Kenya, and South Africa showed that the incidence of HIV infection in circumcised men was 60\% lower than in the uncircumcised men (Murtiastutik, 2008). This finding is completed by previous observation which showed that circumcision had potential to decrease the incidence of HIV infection (Murtiastutik, 2008).

There were three randomized clinical trials in South America which showed that circumcision in men could decrease the incidence of HIV infection around 50-60\% 
in heterosexual men. This finding could increase the enthusiasm to have a circumcision in the area with high prevalence of HIV infection as a routine procedure (Fauci, 2007).

Recent studies in South America (2008) showed that there was an increase in the prevalence of circumcised men (20\%) in the area with high prevalence of HIV infection (Fauci, 2007). Based on Demographic and Health Survey (DHS) in 2007, around $86 \%$ of the total men population ranging from 15-44 years old did not have circumcision in Dominican Republic (Diseker, 2000). Observation by the same institution was done in Altagracia and 94\% men were found uncircumcised (Diseker, 2000).

A longitudinal study for 25 years in New Zealand showed that circumcision was done in 500 men to find the association of circumcision and the risk of sexual transmitted infections. The result showed that there was a decrease of the incidence of sexual transmitted infections in circumcised men (Kebaabetswe dan Lockman, 2003).

A study in Sub-Saharan Africa showed that there was a significant decrease in men who had circumcision as prevention. The result showed a decrease in the prevalence of HIV infection around 6-12\% (Boyle dan George, 2011). In the end of the study, circumcision was found to be an effective way to prevent HIV infection if it was done in 20-30 years old (Boyle dan George, 2011).

The newest meta-analysis which included 27 prospective studies and crosssectional studies showed that the risk of HIV infection in circumcised men was lower than in the uncircumcised men (Fergusson et al., 2010).
An annual increase of HIV incidence in uncircumcised men population, especially uncircumcised men who had unsafe sexual practices (without condoms) encouraged the researcher to investigate the proportion of HIV patients in circumcised men and uncircumcised men.

\section{SUBJECTS AND METHODS}

This was a descriptive study with a crosssectional design study. This study was conducted from August 2013 to February 2014 in special care center in General Hospital Center Haji Adam Malik Medan. The target population was men who had HIV and the accessible population was men with HIV who came to special care center in General Hospital Center Haji Adam Malik Medan from August 2013 to February 2014. The sample in this study was the accessible population who had fulfilled the selected criteria. The sample in this study was based on the total sampling from August to December 2013.

\section{RESULTS}

In this study, 340 HIV patients were having their history taken and physical examination started from August 2013 to February 2014. This study was conducted in special care center in Haji Adam Malik Hospital Medan and all subjects who had undergone the history taking were then having physical examination.

The characteristics of the study population in this study included age, religion, ethnic group, education level, job, and marriage status. The characteristics of HIV patients based on age, ethnic group, education, job, and marriage status were described in Table 1.

Table 1 showed that the highest percentage of HIV infection was found in 31-40 years old group (43.5\%), in which this age group is in their productive age, 
while the lowest percentage was found in 51-60 years old group (3.5\%).

Plank et al., (2010) indicated that the highest HIV infection was in the 15-49 years old group and they were heterosexuals ranged from $50 \%$ to $75 \%$. Study conducted in Botswana, Africa showed that only $15 \%$ men had neonatal circumcision.

\section{Table 1. The characteristics of the study population}

\begin{tabular}{|c|c|c|}
\hline Variable & Percentage (\%) & Frequency (n) \\
\hline \multicolumn{3}{|l|}{ Age (years old) } \\
\hline$>20-30$ & 39.7 & 135 \\
\hline$>31-40$ & 43.5 & 148 \\
\hline$>41-50$ & 13.2 & 45 \\
\hline$>51-60$ & 3.5 & 12 \\
\hline \multicolumn{3}{|l|}{ Ethnic group } \\
\hline$>$ Javanese & 25.6 & 87 \\
\hline$>$ Batak & 40.0 & 136 \\
\hline$>$ Karo & 19.7 & 67 \\
\hline$>$ Malay & 6.2 & 21 \\
\hline$>$ Padang & 6.2 & 21 \\
\hline$>$ Acehnese & 0.6 & 2 \\
\hline$>$ Chinese & 1.8 & 6 \\
\hline \multicolumn{3}{|l|}{ Religion } \\
\hline$>$ Islam & 41.2 & 140 \\
\hline$>$ Christianity & 57.6 & 198 \\
\hline$>$ Buddhism & 1.2 & 4 \\
\hline \multicolumn{3}{|l|}{ Marriage status } \\
\hline$>$ Married & 97.6 & 332 \\
\hline$>$ Unmarried & 2.4 & 8 \\
\hline \multicolumn{3}{|l|}{ Education level } \\
\hline$>$ Primary school & 14.1 & 48 \\
\hline$>$ Junior high school & 10 & 34 \\
\hline$>$ Senior high school & 29.1 & 99 \\
\hline$>$ D3 & 25.6 & 87 \\
\hline$>\mathrm{S} 1$ & 21.2 & 72 \\
\hline \multicolumn{3}{|l|}{ Job } \\
\hline$>$ Farmer & 28.5 & 97 \\
\hline$>$ Worker & 8.2 & 28 \\
\hline$>$ Driver & 12.6 & 43 \\
\hline$>$ Entrepreneur & 17.6 & 60 \\
\hline$>$ Employee & 30.6 & 104 \\
\hline$>$ Student & 0.8 & 2 \\
\hline$>$ Teacher & 1.6 & 6 \\
\hline
\end{tabular}

Kizogi et al., (2011) conducted a study in Rakai District, Uganda. The result showed that the highest age group was 1525 years old (39.4\%) and it was found that men who had broad preputium or men who had not been circumcised were infected more often than men who had been circumcised.

Previous studies indicated that HIV infection was more common in men in their productive age and uncircumcised men because the preputium was more exposed than in circumcised men.

Table 1 indicated that the highest ethnic group in this study was Batak (40\%) and the lowest ethnic group was Acehnese (2\%). In addition, the highest population in this study was Christian (57.6\%), followed by Muslim (41.2\%), and Buddhist (1.2\%) respectively.

Wicken (2010) indicated that the characteristics of the study population 
consisted of Christian (54.3\%), followed by Muslim (34\%), and Catholic (11.7\%).

Several studies showed that the highest prevalence was found in Christian because they did not do circumcision, while Muslim and Catholic had an understanding to have circumcision for health purpose.

Table 1 showed that the prevalence was higher in married subjects (97.6\%) compared to unmarried subjects (2.4\%). In addition, the education level in this study was higher in senior high school (29.1\%), D3 (25.6\%), S1 (21.1\%), and the lowest groups were junior high school (10\%) and primary school (14.1\%) respectively.

A study by Westercamp (2010) in Kenya concluded that the highest population was the senior high school students
(64\%) followed by junior high school students (49\%), and the lowest was in the group who did not go to school.

Previous studies stated that the high prevalence in senior high school students was caused by lack of information about the transmission and prevention of HIV infection.

Table 1 showed that the highest subject population was the employees (30.6\%) and the lowest was the students group (0.8\%). Wilcken (2010) stated that the prevalence in men who had income was $2.14 \%$ and in men who did not work was $0.1 \%$.

Table 2 showed the proportion of HIV infection in circumcised and uncircumcised men.

Table 2 The proportion of HIV patients in circumcised and uncircumcised men who had unsafe sexual practices

\begin{tabular}{lll}
\hline \multicolumn{1}{c}{ Category } & Frequency & Percentage \\
\hline Circumcised & 141 & 41.5 \\
Uncircumcised & 199 & 58.5 \\
Total & 340 & 100 \\
\hline
\end{tabular}

Table 2 showed that the percentage of uncircumcised men who had unsafe sexual practice were $58.5 \%$ and circumcised men who had unsafe sexual practice was $41.5 \%$.

A meta-analysis included 27 studies byReisen et al., (2007) in New York concluded that group who had circumcision was less likely to have HIV infection.

A study by Peresse et al., (2009) in Brazil stated that the prevalence of HIV infection was lower in circumcised group (o.3\%) compared to uncircumcised group (1\%).

A study by Boyle and Hill (2010) in Sub-Saharan Africa stated that HIV infection was higher in circumcised group (61\%) compared to uncircumcised group.

Previous studies showed than HIV infection was higher in uncircumcised group compared to circumcised group. This was caused by the langerhan cells in the preputium, which were the target of HIV, therefore uncircumcised penis had broader exposure to HIV. In conclusion, circumcision can prevent the transmission of HIV. Further studies were needed to investigate the risk factor associated with HIV transmission.

\begin{tabular}{c}
\hline REFERENCES \\
\hline Bailey CR, Moses S, Parker CB, Agot K, \\
Maclean I, Krieger JN, Williams C, \\
Campbell RT (2007). Male circum- \\
cision for HIV prevention in young \\
men in Kisumu, Kenya: a randomized \\
controlled trial. Lancet. 643-65 \\
Boyle JG, Hill G (2011). Sub Saharan \\
African randmissed clinical trials \\
into male circumcision and HIV \\
transmission: Methodological, ethi- \\
cal and legal concerns. JLM.(89)31.
\end{tabular}


Brewer D, Potterat JJ, Robert JM (2007). Associated with prevalent HIV infection in virgin and adolescent in Kenya, Lesotho and Tanzania. J Elsevier; 217-226.

Dinas Kesehatan Provinsi Sumatera Utara (2012). Data survey penyakit infeksi menular seksual dan AIDS/HIV.

Diseker RA (2000). Circumcision and STD in the United State: cross sectional and cohort analyses. Sex Transm Inf. 76:474-479.

Fauci AS (2007). Pathogenesis of HIV disease: oppurtunities for new prevention interventions. CID. 45(4): S206-212.

Fergusson DM, Boden JM, Horwood J (2010). Circumcision status and risk sexually transmitted infection in young adult males: An analysis of longitudinal Birth Cohort. JAP. 213218.

Katz I, Wright AA (2008). Circumcision- a surgical strategy for HIV for prevention in Africa. N Engl J.Med.; 359 (23): 2412-2415.

Kebaabetswe P, Lockman S (2003). Male circumcision: an acceptable strategy for HIV prevention in Botswana. JSTI. 79: 214-219.

Kurt AE, Connie C, Baeten JM (2011). Combination HIV prevention: Significance Challenges and opportunities. Curr HIV/AIDS Rep. 1:62-72.

Lissouba P (2011). Adult male circumcision as an intervention against HIV: an operational study of uptake in a South African community (ANRS
12126). BMC Infectious diseases 11: 253.

Murtiastutik D (2008). AIDS. Editor Jusuf Barakbah, Hans Lumintang, Sumarko Martodiharjo. Buku Ajar Infeksi Menular Seksual. Airlangga University Press Surabaya, 211-214.

Plank MR (2010). Acceptability of infant male circumcision as part of HIV prevention and male reproductive health efforts in Gaborene, Botswana, and surrounding areas. AIDS behave. 14(5): 1198-1202.

Roloff HA, Otieno N, Agotkawango, Achola JN, Bailey RC (2011). Acceptability of medical male circumcision among uncircumcisied men in Kenya one year after the launch of the national male circumsion program. J Plos one. (5): 198-214.

Sancez J, Rosas VG, Hughes JP, Baeten JM, Fuchs J, Buchbinder SP (2011). Male circumcision and risk of HIV acquisition among men who have sex with men from the United States and Peru. AIDS. 25(4):519-523.

Serwadda D (2012). Circumcision of HIVinfected men: Effects on high-risk human papilomavirus infections in a randomized trial in Rakai, Uganda. JID. 1463-1469.

Siegfried N, Muller M, Deeks JJ, Volmink J (2009). Male circumcision for prevention of heterosexual acquisition of HIV in men. J Wiley. 123(34): 23-29.

Simon V, Hod D, Karim QA (2006). HIV/AIDS epidemiology pathogennesis, prevention and treatment. Lancet. 369(9534): 489-504. 